\title{
Unusual Presentation of Differentiated Thyroid Cancer Metastasis
}

\author{
Haissan Iftikhar ${ }^{1} \quad$ Mubasher Ikram $^{1} \quad$ Adnan Yar Muhammad ${ }^{1} \quad$ Karim Rizwan Nathani $^{1}$ \\ ${ }^{1}$ Department of Surgery, Aga Khan University Hospital, \\ Karachi, Pakistan \\ Int Arch Otorhinolaryngol 2018;22:167-170.

\begin{abstract}
Address for correspondence Haissan Iftikhar, BBS, Department of Surgery, Aga Khan University Hospital, Main Stadium Road, Karachi, Sindh 74800, Pakistan (e-mail: haissaniftikhar@gmail.com).
\end{abstract}

\begin{abstract}
Keywords

- thyroid neoplasm

- neoplasm metastasis

- thyroid nodule

Introduction The rates of thyroid cancers are on a rise, especially well-differentiated thyroid cancers. This could be partly due to newer diagnostic modalities, like highresolution ultrasound, that can pick up smaller lesions. Differentiated thyroid cancers with distant metastases are not common, and even rarer is the initial presentation with complaints not related to the neck.

Objectives The objective of this series was to study and report the unusual cases of patients with differentiated thyroid cancer with distant metastasis. There is a lack of data in the literature on these cases, and due to the rarity of such metastases, no definite treatment protocol has been defined.

Methods A retrospective chart review of 1,200 cases of thyroid surgeries was performed. A total of 10 cases of well-differentiated thyroid cancer on the final histopathology exam that had initially presented with usual complaints to departments other than the Otolaryngology Department were identified.

Results A total of 6 patients had papillary carcinoma, whereas 4 patients had follicular carcinoma on final the histopathology exam. Two patients presented with iliac crest lesions, 2 with vertebral lesions one each with parapharyngeal mass, supraclavicular mass, labia majora swelling and bleeding, lung, rib and neck of femur lesion.

Conclusion There are still no specific guidelines on how to address these patients with differentiated thyroid cancer with distant metastasis (except for the cases of bone and lung lesions) and on which treatment should be offered in case of recurrence. More studies on the subject are required.
\end{abstract}

\section{Introduction}

Thyroid cancer comprises $1-5 \%$ of all cancers worldwide. ${ }^{1}$ New cases of thyroid cancer are diagnosed every year, and this rise is attributed to the newer diagnostic modalities, such as highresolution ultrasonography. ${ }^{2}$ Papillary, follicular and Hurthle cell carcinomas of the thyroid fall under the category of welldifferentiated thyroid cancers, and form the bulk of thyroid malignancies. $^{2}$ The overall 10-year survival rate of differen- tiated thyroid cancer lies between $85 \%$ and $95 \%$. This number falls to $50 \%$ for patients with distant metastasis. ${ }^{3}$

The initial presentation of differentiated thyroid malignancy is an increase in the size of the thyroid gland or otherwise neck swelling; however, in very rare cases, the patients present with atypical complaints, and after an evaluation, thyroid malignancy with distant metastasis is revealed. The literature on this subject is as rare as the cases. We report a series of cases of patients who presented with received

March 22, 2017

accepted

May 5, 2017

published online

July 14, 2017
DOI https://doi.org/

10.1055/s-0037-1604038. ISSN $1809-9777$.
Copyright $(2018$ by Thieme Revinter

Publicações Ltda, Rio de Janeiro, Brazil
License terms

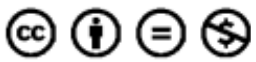


atypical complaints and were diagnosed with well-differentiated thyroid cancer.

\section{Material and Methods}

A retrospective review (descriptive cross-sectional study) of 1,200 cases of patients with thyroid cancer who underwent treatment at a tertiary care hospital was performed. Welldifferentiated thyroid malignancies with distant metastasis were found in 10 patients who presented with complains ranging from lower limb neurological weakness to leg pains. A total of 8 out of the 10 patients were diagnosed by departments outside Otolaryngology, and were then referred the right department for the definitive treatment. All of the patients underwent surgical resection (thyroidectomy) with or without neck dissection, and were subsequently referred to the Endocrinology Department for radioiodine (RAI) ablation.

\section{Results}

A total of 10 patients had distant metastasis at the time of presentation. Eight out of the 10 patients sought other specialties at first, where a biopsy of the lesion was taken; after the diagnosis of thyroid malignancy on the histopathology exam, they were then referred to the Department of Otolaryngology for the definitive treatment. The mean age of the patients was 47.80 (standard deviation [SD]: \pm 9.19 ) years, and their ages ranged from 35 to 65 years. A total of 7 patients were male, and the other 3 were female. Only 1 of the patients underwent total thyroidectomy; 4 underwent total thyroidectomy with central neck dissection; and 5 patients underwent total thyroidectomy with bilateral neck dissection. Nine out of the 10 patients underwent RAI ablation, and 1 patient refused to receive the treatment. The final histopathology exam revealed 6 patients with papillary carcinoma and 4 patients with follicular carcinoma of the thyroid. Two patients presented with vertebral lesions and a cystic lesion in the iliac crest. One of the patients with vertebral lesions had a lower limb weakness that improved over time, but persisted until the last follow-up. Those patients with iliac crest lesions presented with leg pain to orthopedic surgeons, and a biopsy under general anesthesia was performed and revealed a thyroid malignancy. A female presented to the gynecologist with bleeding in the labia majora. Two patients presented to a thoracic surgeon: one of them underwent a trans-thoracic lung biopsy, and the other underwent a biopsy of a cystic lesion of the left rib; both were diagnosed with thyroid malignancy. Another patient presented to an orthopedic surgeon. A lesion on the right femoral neck was detected after a computed tomography (CT) scan, and a biopsy was performed with the patient under general anesthesia. Two patients presented to our department: one with a right supraclavicular lesion to whom fine-needle aspiration cytology (FNAC) was suggested, and the other with oropharyngeal swelling on the left side. An excisional biopsy revealed a thyroid malignancy.
All of the patients then underwent definitive surgery, and were referred to endocrinologists for RAI ablation. A total of 4 patients underwent multiple sessions of RAI ablation over time, receiving as much as $600 \mathrm{mci}$.

All of the patients were followed-up regularly, except for one patient who presented initially with a lesion on her genitalia. At the time of presentation, she had tumor spread outside the thyroid gland. The individual cases are summarized in -Tables 1, $\mathbf{2}$.

\section{Discussion}

Well-differentiated thyroid cancers are usually limited to the thyroid gland. The rates of distant metastasis are reported to range from $4-15 \%{ }^{4}$ Other than the lymph nodes, the most common sites of metastasis are the lung and bones, but involvement of other organs is also reported. ${ }^{4}$ The rate of metastasis to sites other than the lung and bones is $<5 \%{ }^{3}$ As seen in our series, six out of the ten patients had bony metastasis (two in the iliac crest, two vertebral, and one each in the rib and femoral neck). To our knowledge, there is no reported case of metastasis to the labia majora, thus making our case the first to ever be reported.

The presence of distant metastasis at the time of presentation is a significant prognostic factor, as the 10-year survival rate falls to $50 \%{ }^{4}$ Age, gender and involvement of multiple organs are independent factors associated with mortality in thyroid-cancer patients. ${ }^{4}$ Metastasis to the lung and bones are well-understood, and draw significant attention when planning treatment for these patients, but metastasis outside these organs is usually ignored in the clinical setting. This may be due to the rarity of such cases, which explains the lack of literature on the subject.

The prognosis of well-differentiated thyroid cancer has also been shown to be affected by histopathology, with 10-year survival rates as high as $90 \%$ for papillary thyroid cancer, while the rates for follicular and Hurthle cell carcinomas are $85 \%$ and $76 \%$ respectively. ${ }^{3,5}$ The papillary cancer and its variants outnumber follicular and Hurthle cell carcinomas 7 -fold 25 -fold respectively. ${ }^{5}$ Papillary thyroid cancer is known to metastasize via the lymph nodes, whereas follicular thyroid cancer metastasizes hematogenously, which could explain its distant spread when compared with papillary thyroid cancer. ${ }^{3}$ One of our patients had follicular metastasis to labia majora, and this could be explained by the hematogenous spread.

A complex understanding is required for the colonization of thyroid cancer cells in various organs (organ tropism). ${ }^{3}$ Various models, such as the mitogen-activated protein kinase (MAPK) and the phosphatidylinositol 3-kinase/protein kinase B (PI3K/Akt) pathways, have been developed, and they explain the spread of thyroid cancer to extra-cervical sites, but they fail to predict the phenomenon of rare organ metastasis. ${ }^{3}$ The identification of various mediators linked to metastasis in thyroid cancer in the future will be an important step to determine organ tropism. ${ }^{6}$

Blood test for thyroglobulin levels, high-resolution ultrasonography, whole body iodine scan, and fluorodeoxyglucose positron emission tomography (FDG-PET) scan are generally 
Table 1 Patient demographics and treatment characteristics

\begin{tabular}{|c|c|c|c|c|c|c|c|c|}
\hline $\begin{array}{l}\text { Serial } \\
\text { number }\end{array}$ & Age & Gender & Comorbidities & $\begin{array}{l}\text { Initial } \\
\text { presentation }\end{array}$ & Specialty & Surgery & Histopathology & $\begin{array}{l}\text { Radioiodine } \\
\text { ablation }\end{array}$ \\
\hline Case-1 & 45 & Female & - & $\begin{array}{l}\text { Left labia } \\
\text { majora lesion }\end{array}$ & Gynecology & $\begin{array}{l}\text { Total thyroidectomy }+ \\
\text { central neck dissection }\end{array}$ & $\begin{array}{l}\text { Follicular } \\
\text { carcinoma }\end{array}$ & No \\
\hline Case-2 & 35 & Male & - & $\begin{array}{l}\text { D12 vertebral } \\
\text { lesion }\end{array}$ & Neurosurgery & Total thyroidectomy & $\begin{array}{l}\text { Follicular } \\
\text { carcinoma }\end{array}$ & Yes \\
\hline Case-3 & 53 & Male & $\begin{array}{l}\text { Hypertension, } \\
\text { asthma }\end{array}$ & Lung lesion & Thoracic surgery & $\begin{array}{l}\text { Total thyroidectomy }+ \\
\text { central neck dissection }\end{array}$ & $\begin{array}{l}\text { Papillary } \\
\text { carcinoma }\end{array}$ & Yes \\
\hline Case-4 & 57 & Male & $\begin{array}{l}\text { Diabetes, } \\
\text { hypertension, } \\
\text { ischemic heart } \\
\text { disease }\end{array}$ & $\begin{array}{l}\text { Left iliac crest } \\
\text { lesion }\end{array}$ & $\begin{array}{l}\text { Orthopedic } \\
\text { surgery }\end{array}$ & $\begin{array}{l}\text { Total thyroidectomy }+ \\
\text { bilateral neck dissection }\end{array}$ & $\begin{array}{l}\text { Follicular } \\
\text { carcinoma }\end{array}$ & Yes \\
\hline Case- 5 & 48 & Female & - & $\begin{array}{l}\text { Right } \\
\text { supraclavicular } \\
\text { lesion }\end{array}$ & $\begin{array}{l}\text { Head and } \\
\text { neck surgery }\end{array}$ & $\begin{array}{l}\text { Total thyroidectomy }+ \\
\text { bilateral neck dissection }\end{array}$ & $\begin{array}{l}\text { Papillary } \\
\text { carcinoma }\end{array}$ & Yes \\
\hline Case-6 & 65 & Male & Hypertension & $\begin{array}{l}\text { D10-11 } \\
\text { vertebral lesion }\end{array}$ & Neurosurgery & $\begin{array}{l}\text { Total thyroidectomy }+ \\
\text { bilateral neck dissection }\end{array}$ & $\begin{array}{l}\text { Papillary } \\
\text { carcinoma }\end{array}$ & Yes \\
\hline Case-7 & 38 & Male & Hypertension & $\begin{array}{l}\text { Right } \\
\text { parapharyngeal } \\
\text { mass }\end{array}$ & $\begin{array}{l}\text { Head and } \\
\text { neck surgery }\end{array}$ & $\begin{array}{l}\text { Total thyroidectomy }+ \\
\text { central neck dissection }\end{array}$ & $\begin{array}{l}\text { Papillary } \\
\text { carcinoma }\end{array}$ & Yes \\
\hline Case- 8 & 52 & Male & - & Left third rib & Thoracic surgery & $\begin{array}{l}\text { Total thyroidectomy }+ \\
\text { bilateral neck dissection }\end{array}$ & $\begin{array}{l}\text { Follicular } \\
\text { carcinoma }\end{array}$ & Yes \\
\hline Case-9 & 40 & Female & - & Iliac crest & $\begin{array}{l}\text { Orthopedic } \\
\text { surgery }\end{array}$ & $\begin{array}{l}\text { Total thyroidectomy }+ \\
\text { bilateral neck dissection }\end{array}$ & $\begin{array}{l}\text { Papillary } \\
\text { carcinoma }\end{array}$ & Yes \\
\hline Case-10 & 45 & Male & - & Right femoral neck & $\begin{array}{l}\text { Orthopedic } \\
\text { surgery }\end{array}$ & $\begin{array}{l}\text { Total thyroidectomy + } \\
\text { central neck dissection }\end{array}$ & $\begin{array}{l}\text { Papillary } \\
\text { carcinoma }\end{array}$ & Yes \\
\hline
\end{tabular}

used to detect distant metastases in cases of well-differentiated thyroid cancer. ${ }^{3}$ Elevated thyroglobulin levels during follow-up suggests a metastatic or recurrent disease. Levels of thyroglobulin $<0.5 \mathrm{ng} / \mathrm{ml}$ have a negative predictive value of $98 \%{ }^{3,7}$ These patients then undergo surgical resection of the thyroid gland followed by radioiodine ablation. ${ }^{8}$ The challenge in our series was the patients presenting with distant metastasis on the onset of the disease. During this period, these conventional methods of diagnosing thyroid malignancy could not be employed; therefore, those patients underwent either a formal biopsy or FNAC. Once diagnosed with thyroid metastasis, they underwent total thyroidectomy.

Table 2 Follow-up and recurrence

\begin{tabular}{|l|l|l|}
\hline Serial number & $\begin{array}{l}\text { Follow-up } \\
\text { (months) }\end{array}$ & Recurrence (yes/no) \\
\hline Case-1 & No follow-up & Not available \\
\hline Case-2 & 29 months & No \\
\hline Case-3 & 38 months & No \\
\hline Case-4 & 18 months & No \\
\hline Case-5 & 25 months & Yes (thyroid bed) \\
\hline Case-6 & 10 months & Yes (lungs) \\
\hline Case-7 & 49 months & No \\
\hline Case-8 & 52 months & Yes (C7/T1) \\
\hline Case-9 & 35 months & No \\
\hline Case-10 & 74 months & Yes (L2 vertebrae) \\
\hline
\end{tabular}

Even though well-differentiated thyroid cancers have an indolent nature, they may behave aggressively. ${ }^{3}$ The survival rate varies for patients who present with distant metastasis synchronously or metachronously with the primary tumor, with the latter enjoying a better overall survival rate, with the lesions appearing as late as a decade after the initial diagnosis. $^{3}$ Another study reports no significant difference between the overall survival amongst those with distant metastasis at the time of presentation and those developing it after the initial treatment. ${ }^{9}$ However, the disease-free survival rate is better for those with distant metastasis at the time of presentation. ${ }^{9}$ Regression analysis has shown that local control of the disease is a significant predictor of the overall survival and disease-free survival rates. ${ }^{9}$

Due to the paucity of data on extra-cervical metastatic thyroid cancer, there is a lack of consensus as to which treatment should be prescribed for this metastatic disease. According to the revised 2015 American Thyroid Association Management Guidelines for Adult Patients with Thyroid Nodules and Differentiated Thyroid Cancer, RAI therapy should be employed; for bone metastasis, the same can be done, but it is rarely curative. ${ }^{10}$ There are no specific recommendations for the treatment of metastases in sites other than these two. ${ }^{10}$ The use of RAI therapy for RAI-avid lesions is suggested. ${ }^{10}$ The European consensus statement for the management of patients with differentiated thyroid carcinoma recommends the use of surgery, external beam radiotherapy, and RAI ablation for bone metastases. ${ }^{8}$ All of the patients in our series underwent RAI ablation after thyroidectomy, except for the one patient (case-1) who refused RAI. 
There is a lack of data on thyroid cancer presenting initially with distant metastasis; therefore, no definitive guidelines are available. Since the publication of the article by Song et $\mathrm{al}^{4}$ various articles reporting such unusual presentations have been published, as well as a recent systematic review on distant metastasis of differentiated thyroid cancer, ${ }^{3,4}$ but more data are required so that there is a consensus on the treatment of these cases.

\section{Conclusion}

Distant metastasis in different thyroid malignancy is uncommon. The usual site of the distant metastasis is either the lung or the bones, and metastases to organs other than these is rare. The prognosis of the patients with distant metastasis is low, providing a grim picture. Due to the lack of cases of patients with distant metastasis reported in the literature, there are still no definitive guidelines to treat these patients. We suggest and encourage the collection of more data on such patients in order to understand the natural history of the disease process and, consequently, in order to be able to formulate guidelines aiming to help clinicians make the right choice when treating patients with distant thyroid metastasis.

\section{References}

1 Kilfoy BA, Zheng T, Holford TR, et al. International patterns and trends in thyroid cancer incidence, 1973-2002. Cancer Causes Control 2009;20(05):525-531
2 Enewold L, Zhu K, Ron E, et al. Rising thyroid cancer incidence in the United States by demographic and tumor characteristics, 1980-2005. Cancer Epidemiol Biomarkers Prev 2009;18(03): 784-791

3 Madani A, Jozaghi Y, Tabah R, How J, Mitmaker E. Rare metastases of well-differentiated thyroid cancers: a systematic review. Ann Surg Oncol 2015;22(02):460-466

4 Song H-J, Xue Y-L, Xu Y-H, Qiu Z-L, Luo Q-Y. Rare metastases of differentiated thyroid carcinoma: pictorial review. Endocr Relat Cancer 2011;18(05):R165-R174

5 Hundahl SA, Fleming ID, Fremgen AM, Menck HR. A National Cancer Data Base report on 53,856 cases of thyroid carcinoma treated in the U.S., 1985-1995 [see commetns]. Cancer 1998; 83(12):2638-2648

6 Hardin H, Montemayor-Garcia C, Lloyd RV. Thyroid cancer stemlike cells and epithelial-mesenchymal transition in thyroid cancers. Hum Pathol 2013;44(09):1707-1713

7 Kloos RT, Mazzaferri EL. A single recombinant human thyrotropin-stimulated serum thyroglobulin measurement predicts differentiated thyroid carcinoma metastases three to five years later. J Clin Endocrinol Metab 2005;90(09):5047-5057

8 Haugen BR, Kane MA. Approach to the thyroid cancer patient with extracervical metastases. J Clin Endocrinol Metab 2010;95(03): 987-993

9 Lee J, Soh E-Y. Differentiated thyroid carcinoma presenting with distant metastasis at initial diagnosis clinical outcomes and prognostic factors. Ann Surg 2010;251(01):114-119

10 Haugen BR, Alexander EK, Bible KC, et al. 2015 American Thyroid Association Management Guidelines for Adult Patients with Thyroid Nodules and Differentiated Thyroid Cancer: The American Thyroid Association Guidelines Task Force on Thyroid Nodules and Differentiated Thyroid Cancer. Thyroid 2016; 26(01):1-133 